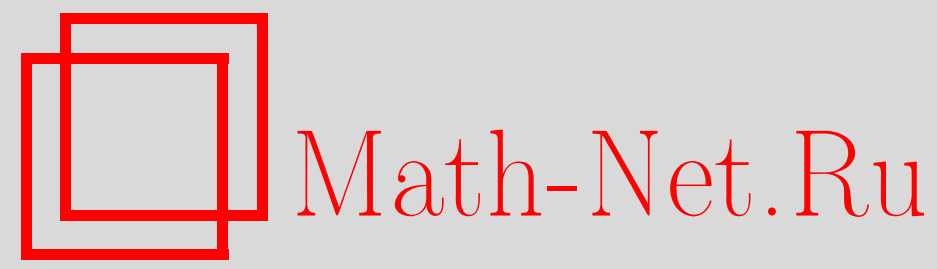

В. А. Ватутин, В. М. Золотарев, Р. И. Ивановская, И. А. Ибрагимов, Ю. В. Прохоров, В. М. Сазонов, Б. А. Севастьянов, А. Д. Соловьев, Д. М. Чибисов, А. Н. Ширяев, Борис Владимирович Гнеденко (1.I.1912-27.XII.1995), Теория вероятн. и ее примен., 1996, том 41, выпуск 2, 393-395

DOI: https://doi.org/10.4213/tvp2948

Использование Общероссийского математического портала Math-Net.Ru подразумевает, что вы прочитали и согласны с пользовательским соглашением http://www.mathnet.ru/rus/agreement

Параметры загрузки:

IP: 34.227 .88 .159

26 апреля 2023 г., $17: 12: 40$

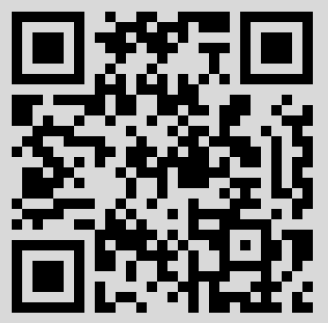




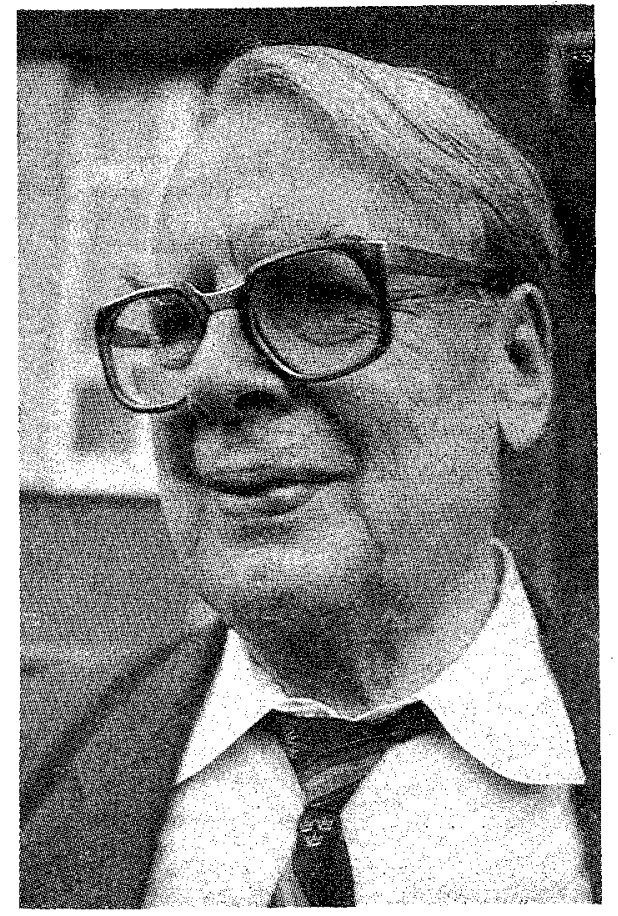

\section{БОРИС ВЛАДИМИРОВИЧ ГНЕДЕНКО}

\section{(1.I.1912-27.XII.1995)}

27 декабря 1995 года в возрасте 84 лет скончался академик Украинской академии наук Јауреат Государственной премии СССР заведующий кафедрой теории вероятностей МГУ профессор Борис Владимирович Гнеденко. Ушел из жизни последний классик из славной плеяды российских вероятностников, в ряду которых такие имена как П. Л. Чебышев, А. А. Марков, А. М. Ляпунов, С. Н. Бернштейн, А. Я. Хинчин, А. Н. Колмогоров, Ю. В. Линник.

Борис Владимирович родился 1 января 1912 г. в г. Симбирске в семье землемера. Очень рано, в возрасте пятнадцати лет, он поступил в Саратовский университет, и через три года окончил его. Несколько лет он работал в Ивановском текстильном институте. Здесь началось его увлечение задачами теории массового обслуживания продолжавшееся затем в послевоенные годы.

В 1934 году Борис Владимирович поступил в аспирантуру Московского Университета, в которой его научным руководителем был А. Я. Хинчин. В тридцатые годы одним из основных направлений в теории вероятностей было исследование предельного поведения сумм независимых случайных величин при неограниченном воз- 
растании числа слагаемых. Эту проблему изучали такие выдающиеся математики как П. Леви, А. Н. Колмогоров, А. Я. Хинчин. Здесь Б. В. Гнеденко предложил новый оригинальный метод введения так называемых сопровождающих безгранично делимых распределений, который позволил ему найти необходимые и достаточные условия сходимости распределений сумм независимых случайных величин к тем или иным конкретным распределениям. По этим работам уже перед самой войной Б. В. Гнеденко защитил докторскую диссертацию. Уже в послевоенные годы все основные исследования по теории суммирования были изложены в совместной монографии Б. В. Гнеденко и А. Н. Колмогорова. Отметим, что в эти годы Борис Владимирович написал большую работу, в которой он нашел полный класс распределений, к которым могут сходиться линейно нормированные члены вариационного ряда - результаты этой работы в последующие годы неоднократно использовались в различных прикладжых задачах.

Сразу же после войны Борис Владимирович переезжает на Украину, где работает сначала во Львове, а с 1950 года в Киеве в Институте математики, в котором он становится заведующим созданного по его инициативе отдела теории вероятностей, а затем директором. Параллельно он преподает в Киевском Государственном университете, где заведует кафедрой математического анализа. В этот киевский период его учениками были И. Н. Коваленко, В. С. Королюк, В. С. Михалевич, А. В. Скороход все они впоследствии стали украинскими академиками. Сам Борис Владимирович в 1945 году был избран членом-корреспондентом, а в 1948 году — действительным членом Украинской академии наук. На Украине Борис Владимирович занимается многими проблемами - он продолжает свои исследования по теории суммирования, распространив предельные теоремы на случай решетчатых случайных величин, проводит вместе с В. С. Королюком интересные исследования по непараметрической статистике. В этот же период появились его исследования по истории математики, из которых отметим монографию «Очерки по истории математики в России». В конце пятидесятых годов Борис Владимирович начинает серьезно заниматься теорией массового обслуживания, читает и издает вместе с И. Н. Коваленко курс лекций.

В 1960 году Б. В. Гнеденхо переезжает в Москву, где становится профессором кафедры теории вероятностей МГУ, а через несколько лет заведующим кафедрой. На этом посту он находился в течение 30 лет до самой своей кончины. В Москве Борис Владимирович заинтересовался новой только что возникшей прикладной наукой математической теорией надежности - и по-существу возглавил коллектив математиков и инженеров, создававших и развивавших эту науку. По результатам этих исследований в 1965 году вышла написанная им в соавторстве с Ю. К. Беляевым и А. Д. Соловъевым монография «Математические методы в теории надежности», переведенная в дальнейшем на семь иностранных языков. В эти же годы вышла написанная совместно с И. Н. Коваленко монография «Введение в теорию массового обслуживания».

Борис Владимирович продолжал вместе со своими учениками исследования по теории суммирования, перенеся их на случай случайного числа слагаемых.

Борис Владимирович воспитал огромное чнсло учеников - это не только российские и украинские математики. Среди его учеников ученые из Германии, Болгарии, Кубы, ряда арабских стран. Всего у него около 50 кандидатов и 20 докторов наук.

Постоянное внимание уделял Б. В. Гнеденко проблемам математического образования в школе и в ВУЗах - им написано большое число статей, брошюр и небольших монографий, посвященных этим вопросам. Широко известен неоднократно переиздававшийся его учебник по теория вероятностей для университетских математиков.

Борис Владимирович всегда остро чувствовал новые актуальные направления в приложениях математики и часто был инициатором развития этих направлений, сплачивая для этой цели вокруг себя коллективы молодых математиков. Этой стороне деятельности Бориса Владимировича во многом способствовали его прекрасные 
человеческие качества — доброта, сердечность, удивительный такт, готовность помочь любому человеху делом или советом. Дом Бориса Владимировича и его супруги Натальи Константиновны был всегда открыт для гостей.

В последние годы, уже будучи тяжело больным Борис Владимирович принял самое активное участие в организации на механико-математическом факультете МГУ небольшого отделения актуарной математики, которое уже четвертый год готовит специалистов в области финансовой математики и страхового дела.

Борис Владимирович был мужественным человеком. До последних лет только самые близкие к нему люди знали, что в 1937 году по чьему-то ложному доносу он был арестован и в течение длительного времени подвергался многочисленным допросам, но никахих ложных показаний от него не добились.

В последние годы Борис Владимирович, перенеся тяжелую операцию, наполовину ослепший, до последнего месяца своей жизни продолжал работать - руководил кафедрой, принимал посетителей, редактировал книги, писал или диктовал свок воспоминания. $\mathrm{K}$ своему восьмидесятилетию Борис Владимирович дал интервью, которое было опубликовано в вып. 4, т. 37 (1992 г.) нашего журнала.

Все, кто знал Бориса Владимировича Гнеденко навсегда сохранят о нем светлую память.

B. A. Bamymus, B. M. Золотарев Р. И. Ивановская, И. А. Ибрагимов Ю. В. Прохоров, В. М. Сазонов Б. А. Севастьянов, А. Д. Соловьев Д. М. Чибисов, A. Н. IIIияяев 